\title{
Economic Conditions and the SEC's Enforcement Process
}

Dr. Mahmoud M. Nourayi, Accounting, Loyola Marymount University

\begin{abstract}
This study analyzes enforcement activities of the U.S. Securities and Exchange Commission (SEC) in conjunction with changes in economic conditions. Neoclassical regulatory theorists argue that regulators are pro-business during periods of economic downturn. However, within the securities market and the regulated reporting environments violations tend to increase during contraction periods. Therefore, more intense enforcement activities seem appropriate during such periods. The intensity of SEC enforcement activities, subject to economic conditions, is examined based on the number of litigation releases issued by the Commission over a twenty year (19721991) period. The test of regulatory behavior revealed that enforcement activities are more intense during economic downturns. Thus the theory that regulators exhibit pro-business behavior during economic contraction is not supported by the results of this study.
\end{abstract}

\section{Introduction}

The Securities Exchange Act of 1934 formally created the Securities and Exchange Commission (SEC) on June 1, 1934. The SEC is bound by law to monitor corporate financial disclosures and to enforce market regulations. Whether the Commission's charge is carried out effectively depends on how market regulations are enforced. Given the financial reporting environment, the significant role of economic conditions may not be ignored in an examination involving the enforcement process.

Peltzman (1976) argued that regulators' actions are calibrated to counter the effect of economic conditions on business. More specifically, Peltzman claims the intensity of enforcement activities by regulatory agencies varies with economic conditions. He suggests the regulator's view is pro-business during a contraction period and pro-consumer during an expansionary period. This practice seems dysfunctional in the financial reporting environment.

Nourayi and Chavis (1994) examined Peltzman's claim in the context of securities market over the period 19771984. Their examination revealed that the enforcement activities were more intense during the periods of poor economic conditions.

The purpose of this study is to re-examine and evaluate the validity of the findings of Nourayi and Chavis (1994) regarding the enforcement of market regulations by the SEC under different economic conditions. This examination involves an evaluation of the enforcement process in the context of the securities market. The article is organized as follows: (1) a description of the enforcement process followed by the theoretical background, (2) a description of the research hypothesis and methodology, and (3) findings and concluding remarks.

\section{The Enforcement Process ${ }^{1}$}

The SEC's Division of Enforcement investigates potential securities market violations and conducts enforcement proceedings against accused violators. The Division is concerned with insider trading, market manipulation, sale of unregistered securities, adherence to the disclosure requirements by public companies, and fraudulent reporting by such companies. The Division administers the enforcement activities through its office within SEC headquarters and the nine regional offices located throughout the United States.

Potential violations may come to the attention of the enforcement staff through various sources such as its own inquiries, other SEC divisions or other government agency referrals, tips from investors and others, news media data, consumers complaints, market surveillance, and inspection of books and records of brokers/dealers. The staff initially evaluates information brought to its attention. If the staff decides to pursue a case on the basis of their initial analysis of the evidence, two alternatives are available: (1) investigation, or (2) matter under inquiry (MUI).

If the enforcement staff believes it has acquired sufficient amount of information to warrant further inquiry, an investigation will be initiated. Opening an MUI, on the other hand, allows the staff 80 working hours to obtain additional information on the case. 
After this additional research is conducted, the staff closes the matter or opens the investigation.

An investigation may be conducted formally or informally. Information about an investigation and/or findings does not become available to the public if no enforcement action is taken. ${ }^{2}$ Conversely, if an investigation results in an enforcement action or series of separate actions against any number of individuals and/or entities involved, the matter is made public by publication in the SEC's Docket.

\section{Theoretical Background}

The role of government in economic activities has been studied and evaluated by scholars with different philosophies, ideologies, and training. Many researchers have questioned the legitimacy of governments' regulatory functions and processes in western societies. Some criticize the government function as pro-capitalist (Ostrovityanov and Reinhold 1963) while others consider it as constraining and threatening to free market operations (Stigler 1964, 1971; Benston 1973, 1976, 1977). There are many researchers, however, who consider the State as the primary means of conflict resolution in social interactions. Lehman (1992, p. 55) states:

In a conflict-based, critical perspective, antagonisms between opposing social constituencies occupy the foreground of the analysis, focusing on the evolution of relations of cooperation and conflict in reproducing collective existence.

The securities market is a prime example of government regulations intended to manage social conflicts. The objective(s) and consequences of the Securities Act of 1933 and the Securities Exchange Act of 1934 have been subject to many studies and intellectual exchanges. Merino and Neimark [1982] argue that the 1933 and 1934 Acts were part of the effort to reconcile the reality of a growing corporate sector with the economic theories and public philosophy of the eighteenth century (page 34). They indicate that ownership of corporate stock by small middle class shareholders was politically effective and facilitated the transition from an agrarian to an industrial society.

Merino and Neimark suggest that disclosure requirements provided a viable mechanism of corporate accountability and deterred demands for more direct governmental intervention in the private sector. They believe market regulations were legitimized by arguments for publicizing information regarding the corporate sector so that potential investments were attracted to profitable activities. The idea was appealing to the politicians and businesses "for it reaffirmed the efficacy of the market model without effecting substantive institutional changes" (Merino and Neimark 1982, p. 36).

It can be argued that government interventions in economic activities stem from market failures or abnormally risky business activities. The events of the 1920s prior to the stock market crash, or more recently the savings and loan fiasco, are examples of such market failures.

Neoclassical economists find market regulations dysfunctional and any government intervention in economic activities distasteful. For example, Stigler (1964) and Benston (1973) concluded that regulation of the securities market had no significant effect on the financial reporting process.

An examination of the railroad and utility companies' risk index by Peltzman (1976) indicates that, immediately after government regulation of these industries, systematic and diversifiable risks were reduced. While Peltzman's conclusion regarding lower risk, due to industry regulations, seems reasonable, his description of regulatory behavior appears to be inconsistent with role of government in a free market environment.

Lehman (1992, p. 69) discusses the linkage between production requirements and social relationships, She also discusses the economic environment of crises and tensions, suggesting that:

Contemporary society is characterized by social relationships based on unequal exchanges and, as in other social orders, this creates a potential for ongoing conflicts and tensions. Periodic economic crises are manifestations of these unresolved tensions, partly as a result of the inequalities built into the social and economic structure.

To consider the effect of economic changes on the financial reporting environment, it should be recognized that managers are essentially the producers of financial reports. During a period of economic crisis, managers stand to lose significantly more than other constituents of the financial reporting environment, mainly the stockholders and creditors, who benefit from diversification. It seems reasonable to assume that the likelihood of securities market violations by market participants increases during economic downturns. That is, due to poor performance and low profitability during such periods, financial incentives for violation of business regulations increase. One former director of the SEC's enforcement division has been quoted, "Anytime you have a recession, you have people who cook the books to give an appearance of contrived profitability" (Kallen 1984).

Peltzman's (1976) position does not encompass Marino and Neimark's account of regulatory process and the role of regulations in maintaining the credibility of 
financial markets. Furthermore, Peltzman's characterization of regulatory activities, a pro-business bias during periods of economic downturn, does not explain the SEC's increased enforcement activities during poor economic conditions observed by Nourayi and Chavis (1994). According to Nourayi and Chavis, Peltzman's specification does not correctly describe the SEC's enforcement process because capture theory is not descriptive of the SEC's role in reporting regulations that affects all public in various industries (Mitnick 1980). However, the relatively short examination period used by Nourayi and Chavis may be critical to the validity of their results.

\section{Research Hypotheses}

According to Peltzman's argument that regulatory behavior is affected by economic conditions and, given the role of the SEC as the securities market regulator, the SEC's enforcement activities would have to be reduced during a contraction period; i.e., the enforcement activity by the SEC relaxes.

On the other hand, the potential for misleading disclosures and false reporting grow with economic downturns. Therefore, one may logically expect to see an increase in the number of actions taken by the Commission during such periods. That is:

$\mathrm{H}_{\mathrm{o}}$ : Ceteris paribus, the number of cases filed by the SEC during periods of economic contraction is significantly smaller than or equal to that during the expansionary periods.

Preliminary evaluation of the data about the enforcement process indicated negative correlation between the average number of cases per year and the index of economic indicators, lagged twelve months. ${ }^{3}$ Figure 1 shows the plot of the average number of cases per year versus the twelfth lag of economic indicators index.
Figure 1

Twelfth Lag Index v. Number of Litigations

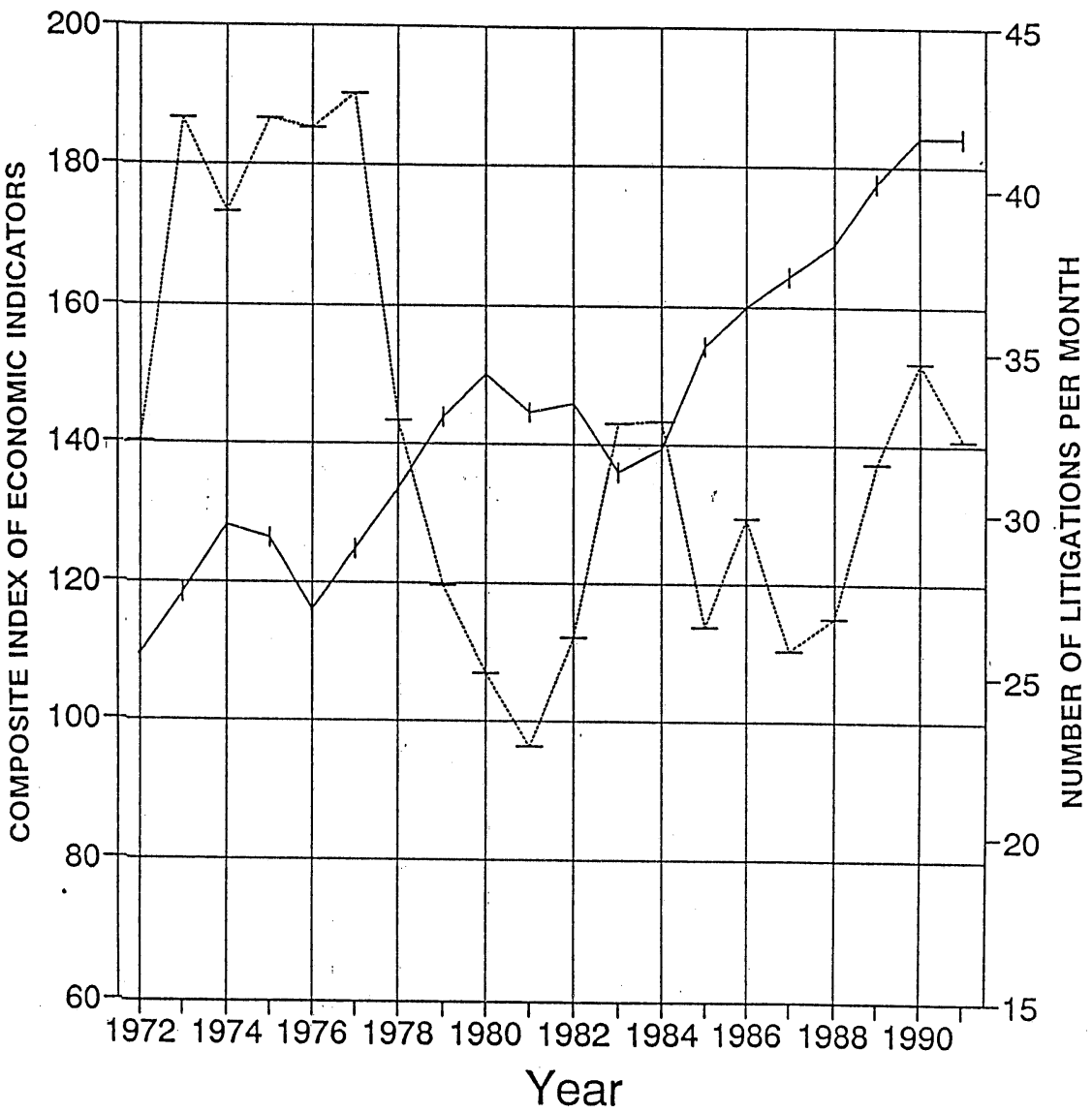

No. of Cases

\section{Methodological Issues}

The twenty-year period from January 1, 1972 through December 31, 1991, is used in this research. The world in general, and the United States in particular, experienced significant changes in the economic conditions during this time period.

The U.S. General Accounting Office (1984), in a special study covering the $1977-1983$ period, reported that the enforcement division received about one third of the total resources of the SEC's funding annually. The GAO report indicated that the number of direct enforcement staff did not change significantly over the same period. It is important, however, to note that the numbers of shares traded on various exchanges, first 
time registrants, broker-dealer registrations, and investment company registrations grew significantly during this period.

\section{Research Design.}

Two sets of procedures, regression-based and nonparametric, were used to examine the economic cycle hypothesis. These procedures are based on the number of cases filed over periods of economic expansion and contraction. All of the litigation cases during the examination period are included in the analysis of this study.

It is necessary to determine the periods of economic contraction and expansion during the years 1972-1991 for the purposes of testing the hypothesis. To determine changes in economic conditions, some surrogate(s) or index of economic activities is generally used. Sources of such an index must be evaluated on the basis of economic significance, statistical adequacy, timing, conformity, smoothness, and currency (U.S. Department of Commerce 1977). For the purpose of this research, the "four roughly coincident indicators", one of the composite indexes published by the U.S. Department of Commerce, is used. ${ }^{4}$ This composite index tends to be a more reliable cyclical indicator than any of its components. Changes in the index were used to identify expansionary (positive) or contraction (negative) periods. One hundred sixty expansionary and eighty contraction months were identified.

During the period covered by this study, five different presidents affiliated with two political parties were in office. Except for the period of 1977-1980, when a Democratic president was in the office, the chairmen of the SEC were appointed by Republican presidents. In light of this condition, the hypothesis of this research was examined while controlling the political variable as indicated by the party affiliation of the executive office of the United States.

In order to ensure that increased volume of market activities in the market does not drive the results, the index of "Net Business Formation" and the number of shares of registered stock sold, for the period of this study, were examined. Both indicators were positively correlated with the economic indicator index, at 0.42 and 0.86 level, respectively. Therefore, changes in the level of market activity will increase the power of the test performed.

To test $\mathrm{H}_{\mathrm{o}}$, the monthly number of litigations filed is regressed on the composite index. Twelve month lags are used to capture the effect of economic conditions at the time the case was initiated. The Ordinary Least Square (OLS) regression approach was used to determine the sign and magnitude of the economic index coefficient. This, in substance, is a covariance test as follows:

$C_{t}=B_{0}+B_{1}$ Index $_{t-12}$

where: $C_{t}$ is the number of litigations filed during month $t$, and Index $x_{t-i}$ is the index for month $t-i(i=12)$.

The hypothesis was tested by examining the significance of $\beta_{1}$. According to the theoretical discussion presented earlier, the expected value of $\beta_{1}$ is smaller than zero. Therefore, the null hypothesis is, $H_{0}: \beta_{1}$ $\geq 0$; this implies a one-tailed test. If the null hypothesis is correct, then $\beta_{1}$ has an expected value significantly larger or equal to zero. If the alternative hypothesis is correct, then $\mathrm{E}\left(\beta_{1}\right)$ is significantly smaller than zero.

The non-parametric tests involve the relative frequency of cases filed by the SEC. For the purposes of this test, the number of litigations during each month was counted. Then, each month was ranked based on the number of litigations during that month. The test statistic $\mathrm{T}$ was computed and the Mann-Whitney test was performed based on the above-explained rankings to examine $\mathrm{H}_{\mathrm{o}}$.

\section{Results}

\section{Regression Tests.}

In this part of the analysis, 240 monthly observations of the number of cases filed by the SEC were used to determine the significance of the economic conditions as the explanatory variable for the number of cases filed during each month.

Regression results, presented in Table 1 , show that the number of cases filed by the enforcement division and the index of economic indicators are negatively correlated at the one percent significance level. The negative sign of the coefficient leads us to believe that enforcement activities increase with economic downturns. The residual auto-correlation test based on the calculated Durbin-Watson is not significant at the five percent level. This indicates that the regression parameters are stable.

To confirm the association between the number of cases and the index of economic conditions, the test period was divided into expansion and contraction subperiods and regression procedures were performed. The results indicate that the coefficient of the economic index in both regressions, expansion and contraction, were negative and statistically significant at the one percent level.

Further analysis revealed that contemporaneous values of the index had no significant relationship with 


\begin{tabular}{|c|c|c|c|c|}
\hline \multicolumn{5}{|c|}{$\begin{array}{c}\text { Table 1 } \\
\text { Regression Analysis of } \\
\text { Economic Cycle Hypothesis }\end{array}$} \\
\hline \multicolumn{5}{|c|}{$\begin{array}{l}\text { Estimated Coefficients } \\
\text { (t-statistic) }\end{array}$} \\
\hline Period & $\begin{array}{c}\text { Constant } \\
\beta_{0}\end{array}$ & $\begin{array}{c}\text { Index } \\
\beta_{1}\end{array}$ & F-Statistic & $\begin{array}{l}\text { Durbin- } \\
\text { Watson }\end{array}$ \\
\hline 20-Year Period 1972-1991 & $\begin{array}{c}53.31 \\
(12.99)\end{array}$ & $\begin{array}{l}-0.144^{*} \\
(-5.15)\end{array}$ & $26.5^{*}$ & $\overline{1.14}$ \\
\hline * Significant at 0.01 level & & & & \\
\hline
\end{tabular}

the number of enforcement cases in a given month.

The effect of economic conditions on the enforcement process, for each type of administration, republican or democratic, was examined separately to ensure that the results were not driven by political changes. Two separate regressions were analyzed and the results were consistent with those presented earlier, i.e., the number of enforcement cases was negatively correlated with the economic indicator and the correlation was statistically significant, at the five percent level in both partitions, regardless of political affiliation of the executive office. The decline in significance of these results, compared to the full regression results is mainly due to the partitioning of the sample.

Non-parametric Tests.

The research hypothesis was tested using the onetailed Mann-Whitney test. The Null hypothesis is:

$$
H_{\circ}: E_{\left\{\begin{array}{l}
\text { Number of cases in a } \\
\text { Contraction period }
\end{array}\right.} \leqq E_{\left\{\begin{array}{l}
\text { Number of cases in an } \\
\text { Expansion period }
\end{array}\right.}
$$

T-values were computed and tested for their significance. The large sample approximation of the critical region was computed, as explained in Conover (1971).

To examine the effect of economic conditions on the enforcement activities of the SEC, as indicated by the number of cases, 240 months during the periods of 1972 1991 were ranked. Each month was classified as either expansionary or contractionary, based the twelve month index used before. The reason for this lagged index is the approximate one-year time period between initiation and disclosure of an enforcement action.

The computed T-value, 6223, was larger than the critical value of $\mathrm{W}_{1-\alpha}, 5220$, for the a equal one percent significance level. Therefore, the null hypothesis, $H_{o}$ is rejected. This conclusion is consistent with that stated earlier based on regression analysis, i.e. the number of enforcement cases is smaller during an expansion period compared to that during a contraction period.

\section{Conclusions}

This research examined the effect of economic conditions on the SEC enforcement process. The results of economic cycle hypothesis tests indicate that the level of enforcement activity is not reduced during periods of economic downturn. The result was as expected and indicative of increased violations during contraction periods. This provided some evidence of coherence of the enforcement process with respect to changes in economic conditions. The findings of this study call into question theory of pro-business regulatory behavior advanced by Peltzman (1976).

These results are not surprising because of the limited theoretical framework employed by Peltzman in considering all regulatory activities. The rejection of the probusiness regulatory behavior theory seems reasonable in the light of the fact that the SEC does not regulate any specific industry and its activities affect all business segments (Lowi 1969). 
While additional chronological information about litigation cases, and more data about resources allocated to the enforcement activities by the SEC may refine the partitioning and enhance statistical procedures, the results presented here provide a better understanding of the SEC's enforcement function in the securities market.

Ronen (1974) and Tinker (1984) show that, in some respects, the political process is driven by economic forces and the two realms of politics and economics are not independent. Tinker (1984, p. 69) states: "The primary distinction between neoclassical and radical state theories lies in their respective treatment of socially structured conflict." Tinker criticizes reductionism in neoclassical theories by trying to explain all institutional and environmental settings in purely economic terms. Tinker is also critical of accounting theorists who assume political voluntarism as the basis of their suggested solution to the accounting practice choice process. Tinker advocates significant changes in the theoretical framework underlying financial disclosure analysis.

\section{Suggestions for Future Research}

Although political changes were controlled for by examination of the enforcement process over Democratic and Republican presidential periods, finer separation and more detailed analysis of the political variable may be desirable. Further research in this area of accounting regulation is necessary to evaluate the effect of the enforcement process on financial reporting and securities markets.

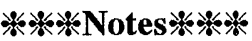

1. See Statistics on SEC's Enforcement Program, a report by United State General Accounting Office, March 1984.

2. During the examination period, over forty percent of all cases investigated were closed without any enforcement action.

3. According to the U. S. General Accounting Office [1984], to initiate civil injunctions and administrative proceedings took 350 and 550 days, respectively, on average.

4. The component of coincident indicators are as follows: (1) employees on nonagricultural payrolls, (2) personal income less transfer payments, (3) industrial production, and (4) manufacturing and trade sales.

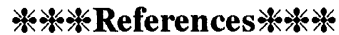

1. Benston, G. J., "Required Disclosure and the Stock Market: An Evaluation of the Securities Exchange Act of 1934," The American Economic Review, Vol. 63, No. 1, pp. 132-155, 1973.
2. Benston, G. J., Corporate Financial Disclosure in the UK and the USA, Saxon House, Lexington Books, 1976.

3. Benston, G. J., "An Appraisal of the Costs and Benefits of Government-RequiredDisclosure:SEC and FTC Requirements," Law and Contemporary Problems, Vol. 41, No. 3, pp. 30-62, 1977.

4. Conover, W. J., Practical Nonparametric Statistics, John Wiley \& Son, Inc., New York, New York, 1971.

5. Kallen, B., "Truth in packaging," Forbes, 12, p. 96, March 1984.

6. Lehman, C., Accounting's Changing Role in Social Conflict, Markus Wiener Publishing, New York \& Princeton, 1992.

7. Lowi, T., The End of Liberalism, W.W. Norton, New York, 1969.

8. Lerino, B. D., and M. D. Neimark, "Disclosure Regulation and Public Policy: A Sociohistorical Reappraisal," Journal of Accounting and Public Policy, Vol. 1, No. 1, pp. 33-57, 1982.

9. Mitnick, B., The Political Economy of Regulation, Colombia University Press, New York, 1980.

10. Nourayi, M. M., and B. M. Chavis, "A Test of Regulatory Behavior: The case of the Securities and Exchange Commission," Rivista Internazionale Di Scienze Economiche E Commerciali, Vol. 41, No. 4, pp. 311-324, 1994.

11. Ostrovityanov, Y., and D. Reinhold, "Monopolies, State, and Crises," Crisis and the Capitalist Cycle, A. Rumyantsev (ed.), People's Publishing House, New Dehli, 1963.

12. Peltzman, S., "Toward a More General Theory of Regulation," Journal of Law and Economics, Vol. 19, No. 2, pp. 211-240, 1976.

13. Ronen, J., "The Need for Accounting Objectives in an Efficient Market," Objectives of Financial Statements, Joe J. Cramer, Jr. and George H. Sorter (eds.), AICPA, pp. 36-52, 1974.

14. Stigler, G. J., "Public Regulation of the Securities Market," The Journal of Business, Vol. 37, No. 2, pp. 117-142, 1964.

15. Stigler, G. J., "The Theory of Economic Regulation," The Bell Journal of Economics and Management Science, pp. 3-21, 1971.

16. Tinker, A., "Theories of State and the State of Accounting: Economic Reductionism and Political Voluntarism in Accounting Regulation Theory," Journal of Accounting and Public Policy, Vol. 3, No. 1, pp. 55-77, 1984.

17. Department of Commerce, Business Conditions Digest, 1977.

18. Department of Commerce, Statistical Abstract of the United States, 1967-1991.

19. General Accounting Office, Statistics on SEC's Enforcement Program, Report B-217030, U.S. GAO, Washington D.C., 1984 